Фармацевтичний менеджмент, маркетинг та логістика

Pharmaceutical management, marketing and logistics

Рекомендована д. фрармац. наук, профр. В. В. Трохимчуком

УДК 615.454.2:[615.1:33

DOI 10.11603/2312-0967.2017.4.8394

\title{
ПОРІВНЯЛЬНИЙ АНАЛІЗ АСОРТИМЕНТУ ЛІКАРСЬКИХ ЗАСОБІВ ДЛЯ ВАГІНАЛЬНОГО ЗАСТОСУВАННЯ НА ФАРМАЦЕВТИЧНИХ РИНКАХ УКРАЇНИ ТА РОСІЙСЬКОї ФЕДЕРАЦІї
}

\author{
() О. М. Глущенко, Ж. М. Полова, Р. М. Хоменко \\ Національний медичний університет імені О. О. Богомольця, Київ \\ chelentechnos@gmail.com
}

\begin{abstract}
Мета роботи. Провести порівняльне дослідження асортименту лікарських засобів для вагінального застосування на фрармацевтичних ринках України та Російської Федерації.

Матеріали і методи. Об'єктами дослідження були Державні реєстри лікарських засобів України та Російської Федерації, інструкції для медичного застосування препаратів. У процесі досліджень використовували наступні методи аналізу: економіко-статистичні, кореляційні, метод організаційно-функціонального моделювання.

Результати й обговорення. Проведено аналіз лікарських засобів для вагінального застосування, що зареєстровані на ринках України та Російської Федерації, встановлено: вітчизняний ринок на 75 \% складається з лЗ іноземного та 25 \% вітчизняного виробництва. Частка іноземних препаратів на ринку РФ становить 53 \%, а вітчизняних - 47 \%. Згідно з класифрікаційною системою АТС, зареєстровані лікарські засоби для вагінального застосування на ринку України представлені двома, а РФ - шістьма фрармакотерапевтичними групами. Представлена номенклатура лікарських засобів для вагінального застосування недостатня для задоволення потреб населення України, тому розробка нових конкурентоздатних (за ефективністю, безпечністю і ціною) ліків є актуальною і сучасною.

Висновки. Проведено порівняльне дослідження асортименту лікарських засобів для вагінального застосування на фрармацевтичних ринках України та Російської Федерації.
\end{abstract}

Ключові слова: фрармацевтичний ринок; асортимент; державна реєстрація; вагінальні лікарські засоби.

Вступ. Інфекційно-запальні захворювання жіночих статевих органів займають особливе місце в структурі загальної захворюваності. Їх значимість зумовлена тим, що ці хвороби уражають органи і тканини репродуктивної системи, i, отже, мають безпосередній вплив на відтворення і продовження роду на землі. Серед патологій, які найчастіше діагностують лікарі-гінекологи, переважають запальні захворювання піхви та вульви (62 \%), шийки матки (51 \%), інфекції, що передаються переважно статевим шляхом (36 \%), запальні захворювання матки (30\%), мікози $(28 \%)$ [1, 2]. Під час вагітності та лактації, при наявності екстрагенітальної патології клінічні лікарі надають перевагу лікарським препаратам місцевої дії, при використанні яких відбувається мінімальна абсорбція та зменшується токсична дія на організм.

Для швидкого та успішного лікування гінекологічних інфекційно-запальних захворювань необхідне застосування лікарських засобів (ЛЗ) з протизапальною, антибактеріальною та протигрибковою активністю. Асортимент вагінальних препаратів різних фрармакологічних груп постійно збільшується шляхом введення в медичну практику нових активних фрармацевтичних інгредієнтів (АФІ), розробки ефективних лікарських фрорм, створення сучасної полімерної упаковки та аплікаторів для їх введення в по- рожнини організму. Незважаючи на досягнутий прогрес у створенні антибактеріальних препаратів, кількість місцевих лікарських фрорм не можна назвати достатньою. Тому розробка нових лікарських препаратів для місцевого застосування залишається актуальним завданням науковців.

Матеріали і методи. Об'єктами дослідження були Державні реєстри лікарських засобів України та Російської Федерації, інструкції для медичного застосування препаратів. У процесі досліджень використовували наступні методи аналізу: економіко-статистичні, кореляційні, метод організаційно-фрункціонального моделювання.

Результати й обговорення. Станом на 1 листопада 2017 року за даними Державних реєстрів лікарських засобів в Україні зареєстровано 114, а в РФ 135 лікарських засобів для вагінального застосування у вигляді різних лікарських фрорм $[3,4]$.

Розподіл лікарських засобів для вагінального застосування за видом лікарської форми наведено на рисунках 1, 2.

Зареєстровані лікарські препарати представлені у вигляді супозиторіїв, таблеток, капсул, кремів, гелів, розчинів, емульсій вагінальних, песаріїв та гранул для приготування вагінального розчину (рис. 1, 2). На фрармацевтичних ринках лікарських засобів для вагі-

ISSN 2312-0967. Фармацевтичний часопис. 2017. № 4 
Фармацевтичний менеджмент, маркетинг та логістика Pharmaceutical management, marketing and logistics

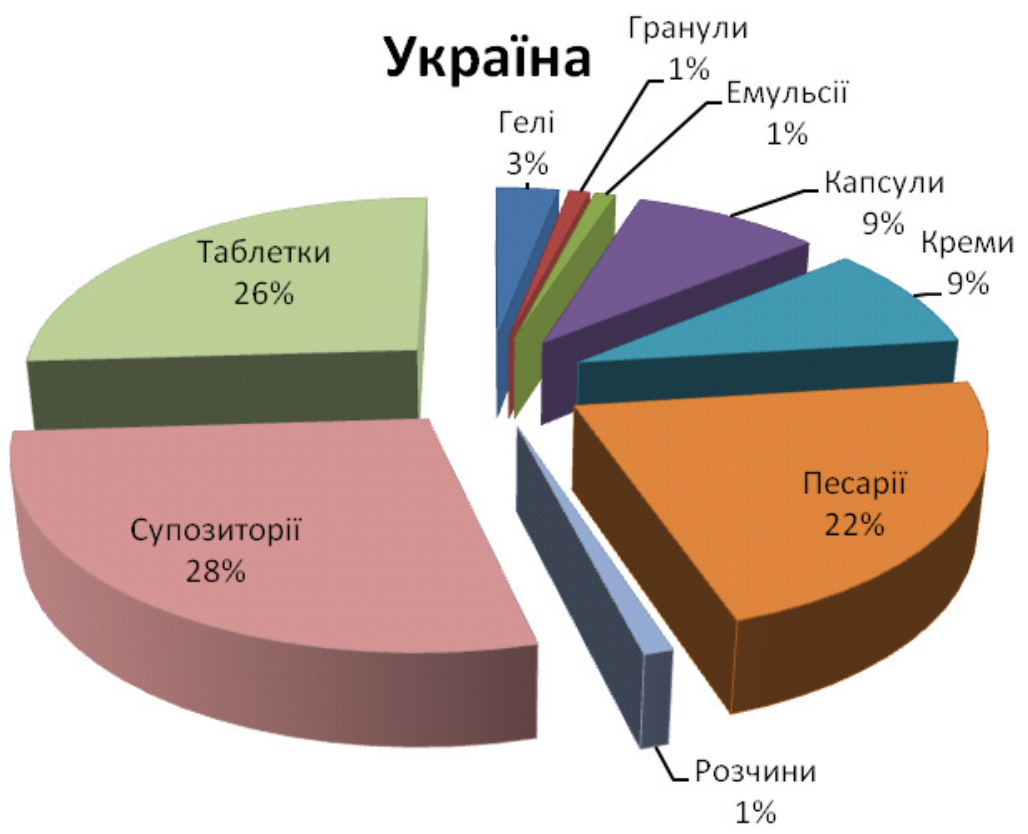

Рис. 1. Розподіл лікарських засобів для вагінального застосування за видом лікарської фрорми на фрармацевтичному ринку України.

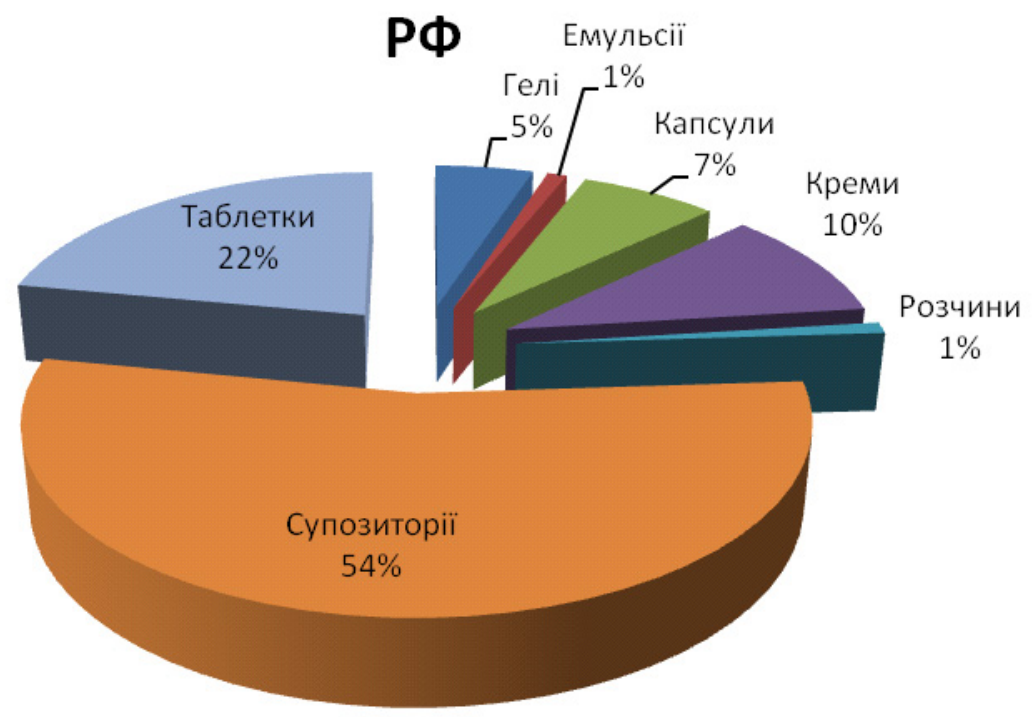

Рис. 2. Розподіл лікарських засобів для вагінального застосування за видом лікарської фрорми на фрармацевтичному ринку Російської Федерації.

нального застосування в Україні та РФ домінують супозиторії і песарії (50 \% і 54 \%) та таблетки - (26 \% і $22 \%$ ); менше кремів (9 \% і $10 \%$ ), капсул (9 \% і $10 \%)$ та гелів (3 \% і 5 \%). Лікарські фрорми у вигляді розчинів, емульсій вагінальних та гранул для приготування вагінального розчину займають відповідно по 1 \%.

Згідно з класисікаційною системою АТС, зареєстровані лікарські засоби для вагінального застосування на ринку України представлені двома, а РФ шістьма фрармакотерапевтичними групами. Український ринок характеризується відсутністю зареє- строваних вагінальних Л3, що належать до груп А засоби, що впливають на травну систему і метаболізм, J - протимікробні засоби для системного застосування, L - антинеопластичні та імуномодулюючі засоби та $\mathrm{V}$ - різні засоби (табл.1). Тому для українського фрармацевтичного ринку є актуальним і доцільним розширення асортименту лз для вагінального застосування за рахунок розробки нових препаратів різної терапевтичної дії [5].

Асортимент даних груп препаратів в Україні фрормують 28 вітчизняних та 86 зарубіжних підприємств-

ISSN 2312-0967. Pharmaceutical review. 2017. № 4 
Фармацевтичний менеджмент, маркетинг та логістика Pharmaceutical management, marketing and logistics

Таблиця 1. Розподіл лікарських засобів для вагінального застосування за АТС-класифікацією на фрармацевтичних ринках України та РФ

\begin{tabular}{|c|c|c|}
\hline \multirow{2}{*}{ Група } & \multicolumn{2}{|c|}{ Кількість (\%) } \\
\hline & Україна & $\mathrm{P} \Phi$ \\
\hline А - Засоби, що впливають на травну систему і метаболізм & 0 & 7 \\
\hline А01 - Засоби для застосування в стоматології & - & 3 \\
\hline $\begin{array}{l}\text { А07 - Антидіарейні препарати; засоби, що застосовуються для лікування } \\
\text { інсрекційно-запальних захворювань кишечнику }\end{array}$ & - & 4 \\
\hline D - Дерматологічні засоби & 5 & 3 \\
\hline D01 - Протигрибкові препарати для застосування в дерматології & 4 & 3 \\
\hline D03 - Засоби для лікування ран та виразкових уражень & 1 & - \\
\hline G - Засоби, що впливають на сечостатеву систему та статеві гормони & 95 & 82 \\
\hline G01 - Протимікробні та антисептичні засоби, що застосовуються в гінекології & 72 & 63 \\
\hline G02 - Інші гінекологічні засоби & 13 & 12 \\
\hline $\begin{array}{l}\text { G03 - Гормони статевих залоз і препарати, що застосовуються при патології } \\
\text { статевої сфери }\end{array}$ & 10 & 6 \\
\hline G04 - Засоби, що застосовуються в урології & - & 1 \\
\hline J - Протимікробні засоби для системного застосування & 0 & 3 \\
\hline J01 - Антибактеріальні засоби для системного застосування & - & 1 \\
\hline J02 - Протигрибкові засоби для системного застосування & - & 1 \\
\hline J05 - Противірусні засоби для системного застосування & - & 1 \\
\hline L - Антинеопластичні та імуномодулюючі засоби & 0 & 4 \\
\hline L03 - Імуностимулятори & - & 4 \\
\hline V- Різні засоби & 0 & 1 \\
\hline V03 - Всі інші лікарські засоби & - & 1 \\
\hline
\end{tabular}

виробників. Серед вітчизняних виробників лідируючу позицію займають ПАТ «Монфрарм» (29\%) та ТОВ «ФАРМЕКС ГРУП» (25\%). На ринку РФ асортимент вагінальних ліків формують 63 вітчизняні та 72 зарубіжні підприємства-виробники. Лідерами серед вітчизняних виробників $€$ ВАТ «Нижфрарм» (16 \%) та ТОВ «Альторарм» (8\%).

Аналіз асортименту лікарських засобів для вагінального застосування за країнами-виробниками (табл. 2) показав, що на фрармацевтичному ринку України за- реєстровані препарати з дев'ятнадцяти, а РФ - 3 сімнадцяти країн. Український ринок вагінальних лікарських засобів на 75 \% представлений продукцією закордонного виробництва, серед яких лідерами є Індія - 13 \%, Німеччина і Італія - по 11 \% та Франція - $10 \%$. На фрармацевтичний ринку Російської Федерації $47 \%$ ліків виготовлені вітчизняними підприємствами, а серед іноземних фрірм-виробників переважає продукція фрранцузьких (9\%), індійських, італійських (8\%) та бельгійських і німецьких компаній по 7 \% відповідно.

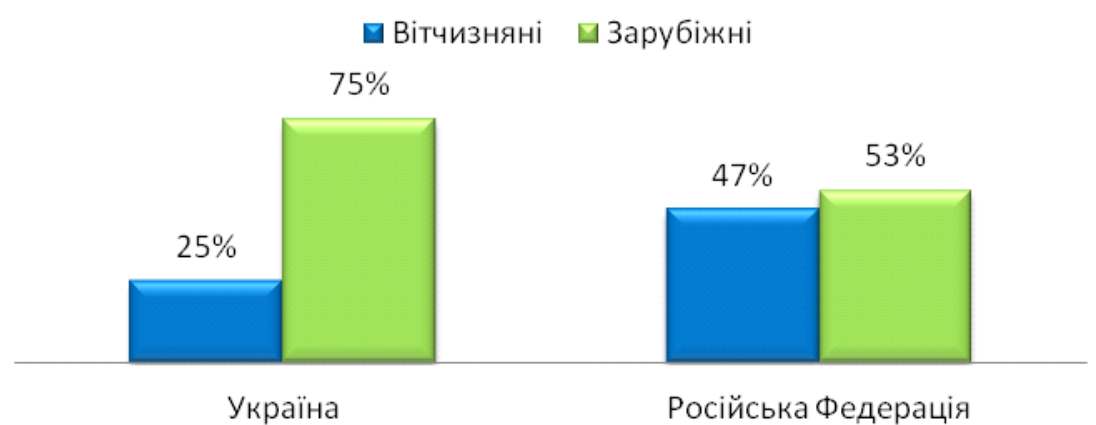

Рис. 3. Порівняння асортименту ЛЗ для вагінального застосування на фрармацевтичних ринках України та РФ за країнами-виробниками.

ISSN 2312-0967. Фармацевтичний часопис. 2017. № 4 
Фармацевтичний менеджмент, маркетинг та логістика Pharmaceutical management, marketing and logistics

Таблиця 2. Аналіз асортименту лікарських засобів для вагінального застосування за країнами-виробниками

\begin{tabular}{|c|c|c|}
\hline Країна-виробник & Ринок України, \% & Ринок Російської Федерації, \% \\
\hline Бельгія & 3 & 7 \\
\hline Великобританія & 1 & 1 \\
\hline Данія & 1 & 1 \\
\hline Ізраїль & 1 & - \\
\hline Індія & 13 & 8 \\
\hline Італія & 11 & 8 \\
\hline Канада & 1 & - \\
\hline Китай & - & 1 \\
\hline Німеччина & 11 & 7 \\
\hline Польща & 6 & 2 \\
\hline Республіка Білорусь & - & 1 \\
\hline Республіка Молдова & 2 & 4 \\
\hline Республіка Словенія & 1 & - \\
\hline Росія & 5 & 48 \\
\hline Румунія & 2 & 2 \\
\hline Сербія & - & 1 \\
\hline США & 2 & 2 \\
\hline Туреччина & 3 & 3 \\
\hline Угорщина & 4 & 2 \\
\hline Україна & 25 & 1 \\
\hline Франція & 11 & 9 \\
\hline Швейцарія & 1 & - \\
\hline
\end{tabular}

Висновки. На підставі аналізу лікарських засобів для вагінального застосування, що зареєстровані на ринках України та Російської Федерації, встановлено: вітчизняний ринок на 75 \% складається з лЗ іноземного та 25 \% вітчизняного виробництва. Частка іноземних препаратів на ринку РФ становить $53 \%$, а вітчизняних - 47 \%. Згідно 3 класифікаційною системою АТС, зареєстровані лікарські засоби для вагінального застосування на ринку України представлені двома, а РФ - шістьма фрармакотерапевтичними групами. Представлена номенклатура лікарських засобів для вагінального застосування недостатня для задоволення потреб населення України, тому розробка нових конкурентоздатних (за еорективністю, безпечністю і ціною) ліків $€$ актуальною і сучасною.

\section{СРАВНИТЕЛЬНЫЙ АНАЛИЗ АССОРТИМЕНТА ВАГИНАЛЬНЫХ ЛЕКАРСТВЕННЫХ СРЕДСТВ НА ФАРМАЦЕВТИЧЕСКОМ РЫНКЕ УКРАИНЫ И РОССИЙСКОЙ ФЕДЕРАЦИИ}

\section{А. Н. Глущенко, Ж. Н. Полова, Р. М. Хоменко}

\section{Национальный медицинский университет имени А. А. Богомольца, Киев} chelentechnos@gmail.com

Цель работы. Провести сравнительное исследование ассортимента лекарственных средств для вагинального применения на фрармацевтических рынках Украины и Российской Федерации.

Материалы и методы. Объектами исследования были Государственные реестры лекарственных средств Украины и Российской Федерации, инструкции по применению препаратов. В процессе исследований использовались следующие методы анализа: экономико-статистические, корреляционные, метод организационно-фрункционального моделирования.

Результаты и обсуждение. Проведен анализ лекарственных средств для вагинального применения зарегистрированных на рынках Украины и Российской Федерации, установлено: отечественный рынок на 75 \% состоит из ЛС зарубежного и 25 \% отечественного производства. Доля иностранных препаратов на рынке РФ

ISSN 2312-0967. Pharmaceutical review. 2017. № 4 
Фармацевтичний менеджмент, маркетинг та логістика

Pharmaceutical management, marketing and logistics

составляет 53 \%, а отечественных - $47 \%$. Согласно классификационной системой АТС, зарегистрированные лекарственные средства для вагинального применения на рынке Украины представлены двумя, а РФ - шестью фрармакотерапевтическими группами. Представленная номенклатура лекарственных средств для вагинального применения недостаточна для удовлетворения потребностей населения Украины, поэтому разработка новых конкурентоспособных (по эфффективности, безопасности и цене) лекарств является актуальной и современной.

Выводы. Проведено сравнительное исследование ассортимента лекарственных средств для вагинального применения на фрармацевтических рынках Украины и Российской Федерации.

Ключевые слова: фрармацевтический рынок; ассортимент; государственная регистрация; вагинальные лекарственные средства.

\title{
COMPARATIVE ANALYSIS OF ASSORTMENT OF VAGINAL MEDICINAL PRODUCTS ON THE PHARMACEUTICAL MARKETS OF UKRAINE AND THE RUSSIAN FEDERATION
}

\author{
O. M. Hlushchenko, Zh. M. Polova, R. M. Khomenko \\ O. Bohomolets National Medical University, Kyiv \\ chelentechnos@gmail.com
}

The aim of the work. Comparative study of the range of medicinal products for vaginal use in the pharmaceutical markets of Ukraine and the Russian Federation.

Materials and Methods. The objects of the study were the State Registers of Medicines of Ukraine and the Russian Federation, instructions for medical use of drugs. In the process of research, the following methods of analysis were used: economic and statistical, correlation, method of organizational-functional modeling.

Results and Discussion. The analysis of medicinal products for vaginal application registered in the markets of Ukraine and the Russian Federation was conducted, it was established that the Ukrainian market consists of $75 \%$ of foreign medicines and $25 \%$ of domestic production. The share of foreign drugs on the Russian market is $53 \%$, and domestic - $47 \%$. According to the ATC classification system, registered medicines for vaginal use in the Ukrainian market are represented by two, and the Russian Federation by six pharmacotherapeutic groups. The presented nomenclature of medicinal products for vaginal application is insufficient to meet the needs of the population of Ukraine, therefore the development of new competitive (in terms of efficiency, safety and price) drugs is relevant and modern.

Conclusions. A comparative study of the assortment of medicinal products for vaginal application in the pharmaceutical markets of Ukraine and the Russian Federation was carried out.

Key words: pharmaceutical market; assortment; state registration; vaginal drugs.

\section{Список літератури}

1. Кремса А. А. Современные ректальные и вагинальные лекарственные формы в гинекологической практике / А. А. Кремса, А. Э. Сподобаева // Молодой учёный. 2016. - № 12 (116). - C. 511-516.

2. Dobaria N. Vaginal drug delivery systems: A review of current status / N. Dobaria, R. Mashru, N. H. Vadia // East and Central African Journal of Pharmaceutical Sciences. 2007. - Vol. 10. - P. 3-13.

\section{References}

1. Kremsa AA, Spodobayeva AE. [Modern rectal and vaginal dosage forms in gynecological practice]. Molodoy uchonyy. 2016;12(116): 511-6. Russian.

2. Dobaria N, Mashru R, Vadia NH. (2007). Vaginal drug delivery systems: A review of current status. East and Central African Journal of Pharmaceutical Sciences. 2007;10: 3-13.
3. Державний реєстр лікарських засобів України [Електронний ресурс]. Режим доступу: http://www.drlz. kiev.ual

4. Государственный реестр лекарственных средств Российской Федерации [Электронный ресурс]. Режим доступа: https://grls.rosminzdrav.ru/grls.aspx

5. Довідник «Компендіум». [Електронний ресурс]. Режим доступу: http://compendium.com.ua

3. Derzhavnyi reiestr likarskykh zasobiv Ukrainy. [Electronic resource]. Available from: http://www.drlz.com.ua/ 4. Gosudarstvennyy reyestr lekarstvennykh sredstv Rossiyskoy Federatsii [Electronic resource]. Available from: https://grls.rosminzdrav.ru/grls.aspx

5. Kompendium. [Довідник «Компендіум»] [Electronic resource]. Available from: http://compendium.com.ua/

Отримано 13.09.2017

ISSN 2312-0967. Фармацевтичний часопис. 2017. № 4 